Brent P. Lavarias, MD

Archimedes B. Bagnes, MD

Gil M. Vicente, MD

Department of Ear Nose Throat - Head and Neck Surgery Jose R. Reyes Memorial Medical Center
Correspondence: Brent P. Lavarias, MD Department of Ear Nose Throat - Head and Neck Surgery Jose R. Reyes Memorial Medical Center Sta. Cruz, Manila 1100

Philippines

E-mail address: blavarias@lycos.com

Reprints will not be available from the author.

No funding support was received for this study. The authors signed a disclosure that they have no proprietary or financial interest with any organization that may have a direct interest in the subject matter of this manuscript, or in any product used or cited in this study.

Presented at the Instrument Design Contest (1st Place) Philippine Society of Otolaryngology Head and Neck Surgery 50th Annual Convention, EDSA Shangri-la Plaza Hotel, Mandaluyong City, December 2, 2006.

\section{Laryngeal Tiririt (Bridge): for Microlaryngeal Surgery Shake}

\begin{abstract}
Objective: To design an instrument for steadying instrument handling during microlaryngeal surgery using an operating laryngoscope.

Method: Our device design takes its cue (pun intended) from professional billiards players like our very own Efren "Bata" Reyes. The laryngeal tiririt (bridge or rake) draws inspiration from the billiards bridge (locally known as tiririt) used to extend the player's reach when the cue ball is too far to make an accurate shot.
\end{abstract}

Setting: The laryngeal tiririt was used and tested by senior residents in microlaryngeal surgeries done in our institution.

Result: The laryngeal tiririt greatly improved the accuracy required in laryngeal surgeries without adding up huge set up or expensive equipment.

\section{Keywords: Laryngoscopes, instrumentation}

EVEN THE world's number one billiards player, Efren "Bata" Reyes, uses a rake or bridge, locally termed as tiririt, to extend his reach on a shot and win many tournaments. The device, sometimes called a "rake" or simply "bridge" is used to extend a player's reach on a shot where the cue ball is too far away to achieve accurate hand bridging (Figure 1). It is from this simple device that we drew inspiration to solve the problem of hand shaking or tremors that many ENT surgeons encounter when performing microlaryngeal surgeries.

Microlaryngeal surgery is a delicate procedure which involves fine hand movements and skills. In a process which demands fine motor skills in a small operating field, steady and precise movement in instrument handling is difficult to achieve for many surgeons. The instrument, which we will fondly name the microlaryngeal tiririt, was designed to address the problem of shaky handling of instruments during microlaryngeal procedures.

The microlaryngeal tiririt operates in similar principle to that of the billiard player's bridge or rake when making a shot at the cue ball. By reducing the shaky handling of instruments, the surgeon can now focus on the precise microlaryngeal surgical procedure at hand. 


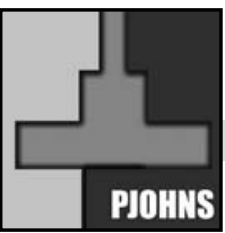

\section{MATERIALS AND METHODS}

The instrument was made of 14-centimeter stainless steel wire (Figure 2) with the distal end flattened and trimmed to form a V-shaped prop or bridge (Figure 3). Its greatest diameter was $1.5 \mathrm{~mm}$. The proximal end was curved and designed to fit to the lip of the laryngoscope for enhanced precision (Figure 4).

\section{RESULTS}

The laryngeal tiririt was utilized on four microlaryngeal surgeries done in our institution. The device was not found to be obtrusive to the already narrow operating field. Since the tiririt was thin, it did not present any intrusion when using the microlaryngeal instruments (Figure 5). No slippage of instruments resting on the tiririt was experienced. The distal V-shaped end of the tiririt could accommodate up to two microlaryngeal instruments at a time. The tiririt also served as a guide, as well as a bridge, for most of the laryngeal instruments used (Figures 6, 7).

\section{DISCUSSION}

The development of rigid endoscopes for ENT surgery has brought our sight closer to the operating site in spite of the narrow operating field ${ }^{1,2,3}$. Extended instruments facilitate microlaryngeal surgery through the operating laryngoscope. However, this makes handling of the instruments unsteady. Various tables have been used to deal with shakiness and strain during surgery by serving as elbow or arm rests. This reduced strain but did not necessarily resolve unsteady handling. Similarly, handles for laryngeal devices ${ }^{4,5}$ (Karl Storz cat. no. 8597, ExplorENT cat. no. 632025) do not necessarily offer a rest from shaking of the distal end of laryngeal instruments. The laryngeal tiririt adds stability in handling instruments during surgery, addressing shakiness and unsteady handling by acting as a mechanical bridge and greatly improving the precision required in microlaryngeal surgeries without adding bulky set up or costly apparatus.

\section{REFERENCES}

1. Jackson C, Jackson CL. Bronchoesophagology. Philadelphia: W.B. Saunders; 1950. p. 35-48

2. Koufman J, Postma G. Controversy in Laryngology. In: Bailey BJ, Calhoun KH, Deskin RW, Johnson JT, Kohut RI, Pillsbury III HC, et al., editors. Head and Neck Surgery-Otolaryngology 2nd ed. Philiadelphia: Lippincott-Raven Publishers; 1998. pp. 859-872.

3. Andrea M, Dias O, Newer Techniques of Laryngeal Assessment. In: Cummings CW, Fredrickson $J M$, Krause CJ, Harker LA, Schuller DE, Richardson MA, editors. Otolaryngology-Head and Neck Surgery, 3rd ed. St. Louis: Mosby; 1998; 103: 1967-1978.

4. Karl Storz GmbH \& Co., Endoscopes and Instruments for ENT 5th ed 1996(catalogue). Tuttlingen (Germany)

5. Explorent GmbH., Micro-laryngoscopy, Broncho-esophagoscopy 4th ed. 2000 (catalogue) Tuttlingen (Germany)

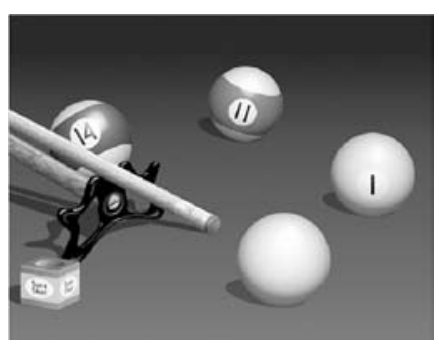

FIGURE 1:

Billiard Bridge

("Billiards" printed with permission from

The Art of Chuck Currey, page 8 available from www.xaraxone.com $/$ Featured Art $/$ mar04/html/08.htm

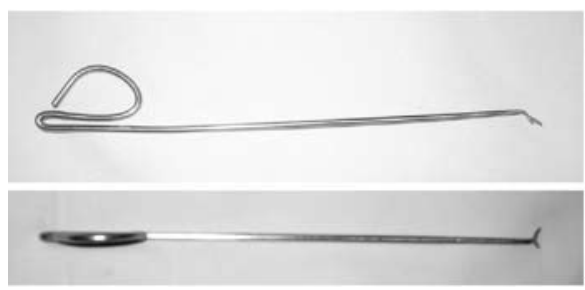

FIGURE 2:

top, lateral view; bottom, antero-posterior view

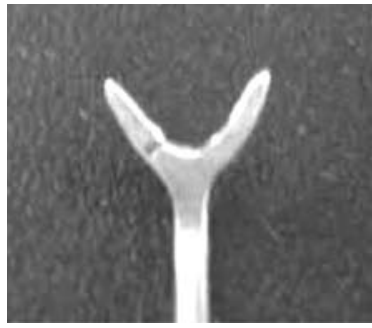

FIGURE 3:

V-shaped distal end
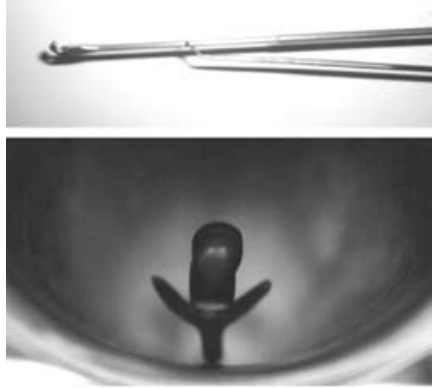

FIGURE 5:

Cup forceps resting on the tiririt

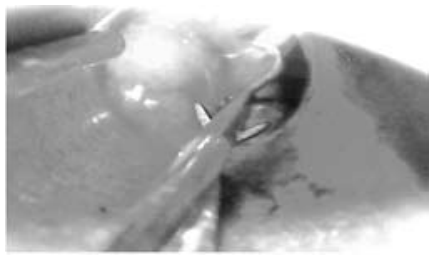

FIGURE 6:

Tiririt with laryngereal ligature needle mounted

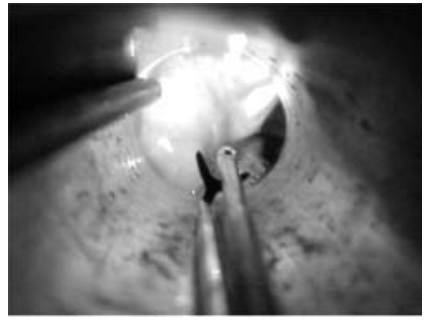

FIGURE 7:

Laryngereal tiririt with cup forceps 